\title{
PENGARUH PEMBERIAN PUPUK N-P-K TERHADAP HASIL BAHAN KERING DAN PROTEIN KASAR RUMPUT Brachiaria humidicola cv. Tully dan Pennisetum purpureum cv. Mott
}

\author{
Novita V. F. Sigar, D. A. Kaligis, W. B. Kaunang dan S. S. Malalantang
}

Fakultas Peternakan Universitas Sam Ratulangi, Manado 95115

\begin{abstract}
ABSTRAK
Telah dilakukan penelitian pengaruh kombinasi pemupukan unsur makro N,P,K terhadap hasil bahan kering dan protein kasar pada rumput Brachiaria humidicola cv. Tully dan Pennisetum purpureum cv. Mott. Penelitian ini menggunakan dua jenis rumput yaitu Brachiaria humidicola cv. Tully dan Pennisetum purpureum cv. Mott dan menggunakan pupuk N-P-K yang di kombinasikan. Perlakuan diatur secara faktorial pada rancangan dasar acak lengkap (RAL) yang terdiri dari 2 faktor, 3 perlakuan dan 4 ulangan. Penerapannya faktor A yaitu rumput yang diuji, $\mathrm{a}_{1}$ : Brachiaria humidicola cv. Tully, $\mathrm{a}_{2:}$ Pennisetum purpureum cv. Mott sedangkan untuk faktor B kombinasi pupuk yaitu $b_{1}: N, b_{2}: N P$ dan $b_{3}: N P K$. Variabel yang diamati yaitu bahan kering dan protein kasar. Hasil analisis keragaman menunjukan bahwa perlakuan memberikan pengaruh yang nyata $(\mathrm{P}<0,05)$ terhadap hasil bahan kering dan protein kasar. Berdasarkan hasil tersebut dapat disimpulkan bahwa kedua rumput uji memberikan respons positif terhadap kombinasi pemupukan N-P-K diukur dari hasil bahan kering dan protein kasar.

significantly $(\mathrm{P}<0.05)$ dry matter and crude protein. Application of factor A indicated that
\end{abstract}

Kata kunci : Pupuk N-P-K, Bahan Kering, Protein, Brachiaria humidicola cv. Tully dan Pennisetum purpureum cv. Mott.

\begin{abstract}
THE EFFECT OF N-P-K FERTILIZER ON THE YIELD OF DRY MATTER AND CRUDE PROTEIN OF GRASS (Brachiaria humidicola cv. Tully and Pennisetum purpureum cv. Mott.). This research was done to evaluate the effect of macro elements N-P-K on the dry matter and crude protein yield of grass (Brachiaria humidicola cv. Tully and Pennisetum purpureum cv. Mott). The research used combination of N-P-K fertilizer. The treatments were arranged in factorial design based on the Completely Randomized Design with two factors, three treatments and four replications. The factor A was applied for testing different grass of Brachiaria humidicola cv. Tully (a1), and Pennisetum purpureum cv. Mott (a2). The factor B was fertilizer combination of N (b1), NP (b2), and NPK (b3). Variables observed were dry matter and crude protein. The results of variance analysis showed that treatment affected
\end{abstract}


both grasses had positively response to the application of N-P-K fertilizer measured on the yield of dry matter and crude protein.

Keywords: N-P-K Fertilizer, Dry Matter, Protein, Brachiaria humidicola cv. Tully and Pennisetum purpureum cv. Mott.

\section{PENDAHULUAN}

Untuk menghasilkan produksi ternak ruminansia harus ditunjang dengan tersedianya hijauan yang cukup dan berkualitas baik sebagai makanan pokok. Rumput Brachiaria humidicola cv. Tully dan Pennisetum purpureum cv. Mott merupakan rumput tropis yang tumbuh dengan baik di areal pertanaman kelapa (Kaligis dan Sumolang, 1991). Rumput ini memiliki kemampuan menahan air yang tinggi dan dapat tumbuh dengan baik pada keadaan tanah yang berat (Aryanto dan Polakitan, 2009). Ginting dan Tarigan (2007) melaporkan bahwa rumput Brachiaria humidicola cv. Tully mengandung bahan kering 321,3 g/kg berat segar. Kandungan nutrisi lainnya yang dinyatakan dalam bahan kering adalah bahan organik 916,2 $\mathrm{g} / \mathrm{kg}$, abu 83,6 $\mathrm{g} / \mathrm{kg}$, protein kasar 87,5 g/kg, NDF 709,1 g/kg, dan ADF 358,6 g/kg. Analisis proximate rumput Pennisetum purpureum cv. Mott mengandung $89,66 \%$ protein kasar, BETN 41,34\%, serat kasar $30,865 \%$, lemak $2,24 \%$, abu $15,96 \%$ dan TDN mencapai $51 \%$.
Kesuburan tanah adalah salah satu faktor yang menentukan hasil yang baik dari hijauan pakan. Ketersediaan unsur hara di dalam tanah dapat dilakukan dengan pemberian pupuk (Sutedjo, 2010). Besarnya jumlah pupuk yang diberikan tergantung respons dari tanaman pakan tersebut. Semakin lengkap unsur hara yang diberikan dengan jumlah yang tepat, semakin baik dan maksimal hasil yang diperoleh (Syarif, 1985).

Unsur hara nitrogen $(\mathrm{N})$, fosfor $(\mathrm{P})$, dan kalium (K) merupakan unsur hara makro yang sangat dibutuhkan untuk pertumbuhan tanaman. Nitrogen merupakan faktor pembatas utama karena sering defisien di lahan sebab sifatnya mudah larut, mudah tercuci dan mudah menguap (Baharsjah, 1983). Unsur ini juga sebagai bahan penyusun protein tanaman, klorofil dan asam nukleat sehingga dapat mamacu produksi tanaman penghasil hijauan pakan serta dapat meningkatkan perkembangbiakan mikroorganisme tanah yang berperan penting menentukan kesuburan tanah (Acehpedia, 2010). Kelebihan unsur nitrogen pada rerumputan tropis akan meningkatkan kandungan oxalate mudah larut (Mani and Kothandaraman, 1980). Selanjutnya, unsur fosfor dan kalium juga dibutuhkan untuk pertumbuhan tanaman terutama pada pastura yang terintegrasi dengan tanaman kelapa, mengingat kelapa sebagai komoditi 
utama banyak membutuhkan kedua jenis unsur hara ini. Namun demikian kelebihan pupuk $\mathrm{K}$ dapat meningkatkan kandungan oxalate larut pada rumput $P$. purpureum (Rahman et al, 2008b) yang dapat bersifat racun bagi ternak (Rahman et al, 2010a).

\section{MATERI DAN METODE PENELITIAN}

\section{Tempat dan waktu}

Penelitian ini telah dilaksanakan di Kecamatan Malalayang 1 Barat lingkungan 1 Kota Manado, berlangsung sejak bulan Oktober 2013 - Februari 2014.

\section{Materi Penelitian}

Bahan dan Alat. Bahan penelitian yang diperlukan adalah Bibit tanaman rumput Brachiaria humidicola cv. Tully dan bibit rumput Pennisetum purpureum cv. Mott dalam bentuk anakan. Pupuk nitrogen (N) dalam bentuk urea, pupuk fosfor $(\mathrm{P})$ dalam bentuk TSP dan pupuk kalium (K) dalam bentuk KCl. Sedangkan peralatan yang diperlukan adalah berupa cangkul, parang, pisau, gunting, timbangan, amplop ukuran besar dan alat tulis - menulis.

\section{Metode Penelitian}

Perlakuan. Perlakuan yang diuji dalam penelitian ini adalah

Jenis rumput sebagai Faktor A :

$\mathrm{a}_{1=}$ Brachiaria humidicola cv. Tully

$\mathrm{a}_{2}=$ Pennicetum purpureum cv. Mott

Dan kombinasi unsur makro sebagai Faktor B :
$\mathrm{b}_{1=\mathrm{N}} \mathrm{N}$

$\mathrm{b}_{2=} \mathrm{NP}$

$\mathrm{b}_{3}=\mathrm{NPK}$

Dengan dosis pupuk urea $=150 \mathrm{Kg} / \mathrm{Ha}$, $\mathrm{TSP}=75 \mathrm{Kg} / \mathrm{Ha}, \mathrm{KCl}=75 \mathrm{Kg} / \mathrm{Ha}$

Rancangan. Perlakuan diatur secara faktorial 2 x 3 dengan Rancangan dasar Acak Lengkap (RAL) sebanyak empat ulangan menurut petunjuk Steel dan Torrie (1994).

Prosedur Kerja. Lahan yang digunakan keseluruhan 50 x 50 meter atau sekitar $2.500 \mathrm{~m}^{2}$. Lahan dibersihkan dari gulma., tanah dibongkar dan digaruk untuk dapatkan partikel tanah yang lebih kecil kemudian diratakan. Lahan dibiarkan selama tiga minggu sampai semua gulma bertumbuh dan disemprot dengan herbisida. Setelah lahan bersih dari gulma, selanjutnya dibuat bedengan seluas $2,5 \times 2,5$ meter .

Pemupukan. Sesuai dosis yang ditetapkan maka jumlah pupuk TSP per petak percobaan sebanyak 101,89 gram, sedangkan pupuk $\mathrm{KCl}$ sebanyak 78,116 gram / petak. Pupuk urea yang digunakan sebanyak 203,804 gram / petak.

Panen. Panen dilakukan setelah rumput uji berumur tumbuh kembali 30 hari setelah pemupukan. Panen dilakukan dengan cara memotong tanaman rumput Brachiaria humidicola cv. Tully $\pm 5 \mathrm{~cm}$ dan rumput Pennisetum purpureum cv. Mott $\pm 10 \mathrm{~cm}$. Pengambilan sampel dilakukan pada setiap 
petak percobaan sebanyak dua cuplikan kemudian diambil sub sampel seberat \pm 500 gram.

Variabel. Variabel yang diukur dalam penelitian ini adalah kandungan bahan kering dan protein kasar kedua jenis rumput uji.

\section{HASIL DAN PEMBAHASAN}

Analisis statistik menunjukan bahwa pengaruh perlakuan pemupukan terhadap produksi bahan kering paling tinggi diperoleh pada interaksi perlakuan $a_{2} b_{3}$ yakni sebesar 33,06 gram/petak yang berbeda nyata lebih tinggi dibandingkan dengan kombinasi perlakuan lainnya. Bila dilihat dari aspek faktor rumput (A) diperoleh bahwa kombinasi pemupukan (faktor B) dengan faktor $a_{2}$ nyata lebih tinggi produksi bahan kering dibandingkan dengan faktor $a_{1}$. Hal ini menerangkan bahwa pemupukan N-P-K lebih direspons positif oleh rumput Pennisetum purpureum cv. Mott dibandingkan dengan rumput Brachiaria humidicola cv. Tully Selanjutnya, bila dilihat dari aspek faktor pupuk (faktor B), kedua jenis rumput uji menunjukkan bahwa kombinasi lengkap pupuk N-P-K memberikan hasil nyata $(\mathrm{P}<$ 0,05) lebih tinggi dibandingkan dengan pupuk $\mathrm{N}$ dan atau NP saja.

Tabel 1. Pengaruh perlakuan terhadap produksi bahan kering dan kandungan protein kasar disajikan pada tabel berikut ini :

\begin{tabular}{ccc}
\hline Kombinasi Perlakuan & Rataan Bahan Kering & Rataan Protein Kasar \\
\hline $\mathrm{a}_{1} \mathrm{~b}_{1}$ & $19,27^{\mathrm{d}}$ & $10,61^{\mathrm{b}}$ \\
$\mathrm{a}_{1} \mathrm{~b}_{2}$ & $20,37^{\mathrm{d}}$ & $10,33^{\mathrm{b}}$ \\
$\mathrm{a}_{1} \mathrm{~b}_{3}$ & $21,54^{\mathrm{c}}$ & $11,57^{\mathrm{a}}$ \\
\hline & & \\
$\mathrm{a}_{2} \mathrm{~b}_{1}$ & $26,51^{\mathrm{b}}$ & $9,88^{\mathrm{b}}$ \\
$\mathrm{a}_{2} \mathrm{~b}_{2}$ & $27,10^{\mathrm{b}}$ & $10,95^{\mathrm{b}}$ \\
$\mathrm{a}_{2} \mathrm{~b}_{3}$ & $33,06^{\mathrm{a}}$ & $11,58^{\mathrm{a}}$ \\
\hline
\end{tabular}

Superskrib berbeda pada lajur yang sama nyata $(\mathrm{P}<0,05)$ 
Secara umum pengaruh interaksi perlakuan pemupukan terhadap protein kasar terlihat sejalan dengan produksi bahan kering. Perbedaannya adalah hasil protein kasar pada interaksi perlakuan pemupukan $a_{1} b_{3}$ ternyata relatif sama dan tidak berbeda dengan interaksi perlakuan $a_{2} b_{3}$. Hal ini menunjukan bahwa kedua jenis rumput uji memberikan respons yang sama terhadap pemupukan unsur hara makro N-P-K secara lengkap.

\section{KESIMPULAN}

Dari hasil penelitian ini dapat disimpulkan bahwa kedua rumput uji memberikan respons positif terhadap kombinasi pemupukan N-P-K diukur dari hasil bahan kering dan protein kasar.

\section{DAFTAR PUSTAKA}

Acehpedia. 2010. Fungsi Unsur Hara. Diakses dari http://acehpedia.org/ Fungsi Unsur Hara. Diakses 10 April 2011.

Aryanto dan D. Polakitan. 2009. Uji produksi rumput dwarf (Pennisetum purpureum $C V$. Dwarf). Jurnal ilmiah, Balai Pengkajian Teknologi Pertanian Sulawesi Utara, JL. Kampus Pertanian Kalasey.

Baharsjah, J.S., Darmawan . J. 1983. Dasar-dasar Fisiologi Tanaman. Penerbit : Suryahdau. Semarang.

Ginting, S.P. and A. Tarigan. 2007. Nutritional quality of
Stenotaphrum secundatum and Brachiaria humidicola for goats JITV11(4): 273-279

Kaligis, D.A and C. Sumolang. 1990. Forage spesies for coconut plantation in North Sulawesi. In Forage for Plantation Corps. Ed. H. M. Shelton and W.W. Stur. ACIAR Proc. No. 32.

Rahman, M. M., Y. Ishii, M. Niimi and O. Kawamura. 2008b. Effects of levels of nitrogen fertilizer on oxalate and somemineral contents in napiergrass (Pennisetum purpureum Schumach). Grassl. Sci. 54:146150.

Rahman, M. M., Y. Ishii, M. Niimi and O. Kawamura. 2010a. Interactive effects of nitrogen and potassium fertilization onoxalate content in napiergrass (Pennisetum purpureum). Asian-Aust. J. Anim. Sci. 23:719-723.

Steel, R. G. D and Torrie, J. H. 1994. Prinsip dan Prosedur Statistik. Diterjemahkan oleh Bambang Sumantri Edisi ke-Dua. PT. Gramedia Pustaka Utama. Jakarta.

Sutedjo, M. M. 2010. Pupuk dan Cara

Pemupukan. Jakarta : PT. Rieneka Cipta.

Syarif, S. 1985. Kesuburan Tanah dan Pemupukan Tanah Pertanian. Pustaka Buana. Bandung.

Mani, A. K. and G. V. Kothandaraman. 1980. Influence of nitrogenand stages of cutting on the oxalic acid content of hybridnapiergrass varieties. Madras Agric. J. 67:678-679. 